International Review of Research in Open and Distributed Learning Volume 18, Number 7

November - 2017

\title{
First Year Learning Experiences of University Undergraduates in the Use of Open Educational Resources in Online Learning
}

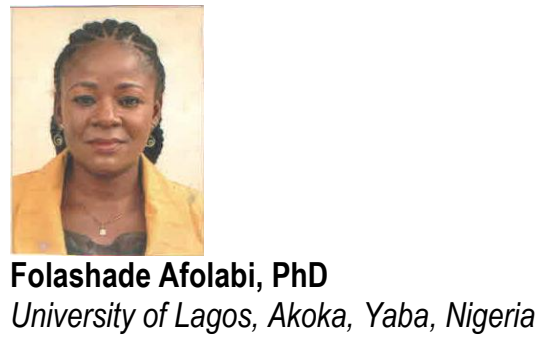

\begin{abstract}
This study investigated -the first year University undergraduates' experiences in the use of open educational resources (OER) in online learning and their in-course achievement. The design selected for the study was survey and quasi-experimental. A total number of 106 University undergraduates participated in the study after a preliminary study was conducted to ascertain undergraduates' perception and acceptability of OER. A structured questionnaire on 4-point Likert scale and Achievement Test were used to collect data. The two instruments were validated and trial tested to established reliability using Cronbach's alpha. Data were analysed using simple percentage and t-test. The results clearly shown that understanding of online learners' skills, acceptability, perception, and competencies is necessary to provide intervention strategy and appropriate support service which could facilitate their understanding and learning of difficult concepts. It was also discovered that that students that have positive perception of OER performed very well in the achievement test administered.
\end{abstract}

Keywords: open and distance education (ODE), e-learning, learning management system (LMS), open education resources (OER)

\section{Introduction}

First year undergraduates are faced with challenges of adjusting to new expectations for learning when transitioning from secondary education to University education. This is especially true for Open and Distance Education (ODE) where learners are expected to transform from passive to active learners providing opportunities to explore and acquire new knowledge on their own (Prensky, 2001; Secreto, 2013). 
Facilitating Physics courses in Distance Learning Institute, University of Lagos, Nigeria could be challenging as facilitators are confronted with the problem of learners coming with different previous knowledge of Physics background from their secondary schools education. Comprehending and mastering quantitative concepts characterized by Physics courses, and connecting them to real life situations are among challenges facing learners. Another prominent challenge is that a fraction of first year undergraduates are not versatile in the use of technological tools for learning. These could be some reasons why first year undergraduates underachieved in Physics courses in their first year. To support learners, the Institute provides printed learning materials and the Learning Management System (LMS) which covers a wide range of different applications such as assignment, quiz, wiki, workshop, forum, lessons, etc.

Distance Learning Institute (DLI), University of Lagos provides support services for their undergraduates where they can interact with facilitators, ask questions, discuss and brainstorm with their peers while a facilitator clarifies their misconceptions, and grades assignments given online. Efforts of the Institute were channeled towards creating educational experience of equal qualitative values for learners to suit their needs outside the classroom. Despite these efforts put in place, undergraduates' academic achievement in some concepts in physics has not improved to an appreciable level. Hence, there is a need to introduce, adopt, and adapt more viable support services which involves active participation, capable of sustaining and stimulating the interest of learners for a better academic achievement in Physics. Therefore, the thrust of this paper is to investigate the experience of first year University undergraduates exposed to the use of OER in online learning. The hope is that the use of OER will contribute appreciable academic achievement of undergraduates in physics.

Open Educational Resources (OER) are defined as technology enabled open provision of educational resources for consultation, use, and adaptation by a community of users for non-commercial purposes (Harsasi, 2015). Downes (2011) defined OER as materials used to support education that may be freely accessed, reused, modified, and shared by anyone. In the same vein, Organisation for Economic Cooperation and Development (2007) defined OER as digitized materials offered freely and openly for educators, students, and self-learners to use and reuse for teaching, leaning, and research.

OER was first used by UNESCO in 2002 at its forum on the impact of Open Courseware for Higher Education in Developing countries, and has since then gained significant prominence in recent years throughout the world (Hew \& Cheung (2013). Types of OER include lessons, modules, full courses/programmes, guides, e-texts, articles, audio tracks, videos, multimedia, and any other learning materials (Hylen, 2007; Baloyi, 2014). OER has been designed to support learning by providing easy accessibility, and potential to reduce barriers to learning through enhanced attention, motivation, and engagement of students (Sclater, 2010).

The advantages of using OER as outlined by Harsasi (2015) include the followings:

- the materials are free to use no subscription fee attached,

- there is easy accessibility to materials, 
- there is continuous access to resources without restriction,

- OER provides students the ability to pursue topics thoroughly, and learn for personal knowledge or enjoyment, and

- $\quad$ OER are available in different visual representations among others.

However, barriers associated with the use of OER as enumerated by D'Antoni (2009) are:

- the broad band access,

- time and expense associated with gaining permission to use third party owned copyrighted materials or its removal from material,

- inadequate resources to invest in the necessary software and hardware,

- lack of skills needed to use technology, and

- lack of academic recognition of the development of OER by teaching staff.

Despite barriers enumerated above, the use of OER has demonstrated its effectiveness for educational contributions in recent years. Hilton and Laman (2012) compared the performance of 690 students using open textbooks in an introductory psychology class to the performance of 370 students who used a traditional textbook in a previous semester. They concluded that students who used the open textbook achieved better grades in the course, had a lower withdrawal rate, and scored better on the final examination.

Additionally, undergraduates believed that having a connection between face-to-face and OER enable them to receive knowledge from multiple sources, to relate to the subject matter of the course, and to gain confidence in applying acquired knowledge into practice (McCarthy, 2010).

According to Kember, McNaught,Chong, Lam, and Cheng (2010), and Resis and Steffens (2010), they found that students believed using interactive technologies helped them to increase learning productivity, encouraged a deeper approach to learning productivity, encouraged a deeper approach to learning, promoted the development of communication skills, and improved their understanding of course content.

Hew and Cheung (2013) found out that the use of OER has been limited to the western countries and only very few students believed that an open courseware site would be valuable to enhance their own knowledge about certain topics. Research on the use of OER in Africa is new and uncommon. This study therefore, will investigate the experience of first year University undergraduates when exposed to the use of OER for learning difficult concepts in physics. However, a preliminary study is required to ascertain level of their acceptability and perception of using OER.

\section{Theoretical Framework}


This study is founded in Diffusion of Innovation (DOI) Theory of Learning. Diffusion of innovation theory is the process by which an innovation is communicated through certain channels over time among the members of a social system (Rogers, 2003). The characteristics which determine an innovation's rate of adoption are: relative advantage, compatibility, complexity, trialability, and observability to those people within the social system.

Though, Rogers (2003) opined that innovation offering more relative advantage, compatibility, trialability, and observability will be adopted faster than other innovations. He then cautioned that getting a new idea adopted, even when it has obvious advantages, is difficult. Therefore, the availability of all these variables of innovations speeds up the innovation-diffusion process (Baloyi, 2014).

\section{Statement of the Problem}

This study attempts to explore the learning experiences and achievement of first year University undergraduates when exposed to the use of OER (audios and video clips) in learning difficult concepts in Physics.

\section{Purpose of the Study}

The study is specifically designed to achieve the following objectives:

1. To determine if the introduction of OER is a useful innovation to online learning by University undergraduates.

2. To determine if introduction of OER is compatible with learners' past experience or change of work habit is required.

3. If the use of OER is comfortable to be used by undergraduates in online learning

4. If the use of OER will improve first year undergraduates' understanding difficult concepts in Physics

\section{Research Questions}

For the purpose of the objectives stated above, the following research questions were raised:

1. Does OER have user advantages?

2. Is the use of OER compatible with past experience?

3. Does OER allow trial ability with respect to gender?

4. Is the result of using OER visible to you? (learners?)

5. Is OER difficult to use and understand?

\section{Research Hypothesis}


The following hypothesis are tested at $\mathrm{P}<0.05$

- There is no significant difference between achievement of first year undergraduates exposed to the use OER and those not exposed to OER in learning difficult concept in Physics

- There is no significant difference between pre-test and post-test performances of undergraduates exposed to OER and those not exposed to OER

\section{Research Method}

This study adopted survey and quasi-experimental research designs. The survey was used as a preliminary study to examine the acceptability and perception of OER usage by undergraduates before designing and applying OER as an intervention for teaching difficult concepts in Physics. The population consisted of all University undergraduates of Distance Learning Institute, University of Lagos in the Department of Education Science who registered for courses in Physics either as elective or compulsory at first year. Thirty-five undergraduates were used as control where 71 were used for the main experiment. A total number of 106 undergraduates participated in the study. Data were gathered from them by sending a 19item questionnaire to predetermine responses whereby the experience and perceptions of University undergraduates can be measured via e-mail. All questions were answered on 4-point Likert scale; Strongly Disagree $=\mathrm{SD}$, Disagree D, Agree $=\mathrm{A}$ Strongly Agree $=\mathrm{SA}$. Thereafter, OER Physics Achievement Test (OPAT) was administered to ascertain if the intervention was able to improve their achievement in understanding difficult concepts in Physics (Waves) more so, if it is gender friendly. To identify difficult concepts, the researcher sampled the opinion of learners by asking them to identify the most perceived difficult concepts in Physics via e-mail. Their various responses were collated as displayed in the Table 1.

Table 1

Undergraduates' Rating of Physics Concepts Difficulty

\begin{tabular}{|l|l|l|l|l|}
\hline Concepts & Motion & $\begin{array}{l}\text { Nuclear } \\
\text { Physics }\end{array}$ & Waves & $\begin{array}{l}\text { Conservation } \\
\text { principles }\end{array}$ \\
\hline \hline $\begin{array}{l}\text { Frequency of } \\
\text { occurrence }\end{array}$ & 14 & 16 & 29 & 12 \\
\hline \hline Percentages & 19.72 & 22.54 & 40.85 & 16.90 \\
\hline
\end{tabular}

University undergraduates rated waves PHS 205) has the most difficult concepts among others with highest frequency of (29) and highest percentage (40.85\%). This supports the findings of (Ownioduokit, 2000) which pointed out that waves is a concept involving a function of two variables -distance and timewhere other concepts and situations require a function of a single variable.

Facilitators exposed all first year undergraduates to interaction with OER for one week using topic one as an example. There-after, first year undergraduates were left to interact with and search for relevant OER on their own and provide answers to questions raised for a duration of two weeks on the stated topics. At 
the end of the due date, questionnaires were collected and analysed according to the stated research questions. The results obtained allowed the researcher to design an intervention. A total number of 86 questionnaires were sent out to learners, only 71 questionnaires were returned.

The test of reliability result of the responses on first year University undergraduates experience in the use of OER was calculated to be 0.855 using Cronbach's alpha. This indicates that the instrument is reliable. Generally, there is an internal consistency of the answers provided by the respondents and therefore, the data do not violate the assumptions of reliability.

\section{Results}

\section{Research Question 1: Does OER Have User Advantage?}

Table 2

Relative Advantage of Using OER

\begin{tabular}{|l|l|l|l|l|l|l|}
\hline Items & \multicolumn{2}{|l|}{ Frequency (\%) } & \multicolumn{2}{l|}{ Mean response rating } \\
\hline \hline & SD & $\mathrm{D}$ & $\mathrm{A}$ & SA & Mean & SD \\
\hline $\begin{array}{l}\text { The OER is a positive } \\
\text { innovation }\end{array}$ & $\begin{array}{c}2 \\
(2.8)\end{array}$ & $\begin{array}{l}6 \\
(8.5)\end{array}$ & $\begin{array}{l}23 \\
(32.4)\end{array}$ & $\begin{array}{l}40 \\
(56.3)\end{array}$ & 1.82 & 0.703 \\
\hline \hline $\begin{array}{l}\text { OER makes it more } \\
\text { convenient to communicate } \\
\text { with facilitators and friends }\end{array}$ & $\begin{array}{l}4 \\
(5.6)\end{array}$ & $\begin{array}{l}19 \\
(26.8)\end{array}$ & $\begin{array}{l}33 \\
(46.5)\end{array}$ & $\begin{array}{l}15 \\
(21.1)\end{array}$ & 2.17 & 0.828 \\
\hline \hline Using OER saves time & 3 & $\begin{array}{l}5 \\
(7.0)\end{array}$ & $\begin{array}{l}38 \\
(53.5)\end{array}$ & $\begin{array}{l}25 \\
(35.2)\end{array}$ & 1.80 & 0.749 \\
\hline \hline $\begin{array}{l}\text { OER makes learning more } \\
\text { meaningful }\end{array}$ & $\begin{array}{l}10 \\
(14.1)\end{array}$ & $\begin{array}{l}2 \\
(2.8)\end{array}$ & $\begin{array}{l}17 \\
(23.9)\end{array}$ & $\begin{array}{l}42 \\
(59.2)\end{array}$ & 1.96 & 0.706 \\
\hline \hline OER is the fast and efficient & $\begin{array}{l}13 \\
\text { way of getting information }\end{array}$ & $\begin{array}{l}7 \\
(9.9)\end{array}$ & $\begin{array}{l}23 \\
(32.4)\end{array}$ & $\begin{array}{l}28 \\
(39.4)\end{array}$ & 2.06 & 0.954 \\
\hline
\end{tabular}

Table 2 shows that 40 (56.3) and 28 (39.4) strongly agree that OER is a positive innovation and fast and most efficient way of getting information. Few of learners disagree $(12+23)$ that OER make it more convenient to communicate with facilitators and friends and makes learning more meaningful. If the good responses are merged together, one could conclude that OER has a relative advantage in its usage in online teaching of physics concepts. This is in agreement with the findings of Harsasi (2015) that OER enhances students' online learning and facilities usage.

\section{Research Question 2: Is OER compatible With Your Past Experience}

Table 3

Compatibility of OER

\begin{tabular}{|l|l|l|l|l|l|l|}
\hline Items & \multicolumn{3}{|l|}{ Frequency (\%) } & \multicolumn{2}{l|}{ Mean response rating } \\
\hline \hline & SD & D & A & SA & Mean & SD \\
\hline $\begin{array}{l}\text { Using OER would require me to } \\
\text { change my study habit }\end{array}$ & \begin{tabular}{l} 
(22.5) \\
\hline
\end{tabular} & $\begin{array}{l}5 \\
(7.0)\end{array}$ & $\begin{array}{l}18 \\
(25.4)\end{array}$ & $\begin{array}{l}32 \\
(45.1)\end{array}$ & 2.11 & 0.871 \\
\hline
\end{tabular}




\begin{tabular}{|c|c|c|c|c|c|c|}
\hline $\begin{array}{l}\text { I am eager to respond to the } \\
\text { discussion group on OER via LMS }\end{array}$ & $\begin{array}{l}17 \\
(23.9)\end{array}$ & $\begin{array}{l}3 \\
(4.2)\end{array}$ & $\begin{array}{l}22 \\
(31.0)\end{array}$ & $\begin{array}{l}29 \\
(40.8)\end{array}$ & 2.01 & 0.853 \\
\hline $\begin{array}{l}\text { OER is compatible with the way I } \\
\text { work }\end{array}$ & $\begin{array}{l}15 \\
(21.1)\end{array}$ & $\begin{array}{l}8 \\
(11.3)\end{array}$ & $\begin{array}{l}23 \\
(32.4)\end{array}$ & $\begin{array}{l}25 \\
(35.2)\end{array}$ & 2.11 & 0.994 \\
\hline $\begin{array}{l}\text { Using OER increases my interaction } \\
\text { with the subject matter }\end{array}$ & $\begin{array}{l}10 \\
(14.1)\end{array}$ & $\begin{array}{ll}2 \\
(2.8)\end{array}$ & $\begin{array}{l}17 \\
(23.9)\end{array}$ & $\begin{array}{l}42 \\
(59.2)\end{array}$ & 1.96 & 0.706 \\
\hline
\end{tabular}

Table 3 clearly displayed that the majority of University undergraduates found OER compatible with their study habits (45.1 and 25.4) and the ways they work, which must have led to increase in interaction with subject matter (59.2 and 23.9) and eagerness in responding to discussions on the LMS (40.8 and 31.0). This could be as result as stated by Rumble, (2000 Govender, Dhurup, and Mudaly (2014), that new generation of learners witnessing the era of digital technologies which has been fully integrated into their lives that could be a reason while OER was able to change their study habit.

\section{Research Question 3: Does OER Allow Trialability?}

Table 4

Trialability of the OER

\begin{tabular}{|l|l|l|l|l|l|l|}
\hline Items & \multicolumn{2}{l|}{ Frequency $(\%)$} & \multicolumn{2}{l|}{ Mean response rating } \\
\hline \hline & SD & D & A & SA & Mean & SD \\
\hline OER does not intimidate me & $\begin{array}{l}9 \\
(12.7)\end{array}$ & $\begin{array}{l}7 \\
(9.9)\end{array}$ & $\begin{array}{l}25 \\
(35.2)\end{array}$ & $\begin{array}{l}30 \\
(42.3)\end{array}$ & 2.42 & 0.839 \\
\hline $\begin{array}{l}\text { I am confident in my ability to } \\
\text { use OER }\end{array}$ & $\begin{array}{l}11 \\
(15.5)\end{array}$ & $\begin{array}{l}8 \\
(11.3)\end{array}$ & $\begin{array}{l}11 \\
(15.5)\end{array}$ & $\begin{array}{l}41 \\
(57.7)\end{array}$ & 2.27 & 0.910 \\
\hline $\begin{array}{l}\text { I do trial and error in working } \\
\text { with OER }\end{array}$ & $\begin{array}{l}10 \\
(14.1)\end{array}$ & $\begin{array}{l}10 \\
(14.1)\end{array}$ & $\begin{array}{l}17 \\
(23.9)\end{array}$ & $\begin{array}{l}34 \\
(47.9)\end{array}$ & 2.38 & 0.909 \\
\hline \hline $\begin{array}{l}\text { I can learn at a comfortable } \\
\text { pace using OER }\end{array}$ & $\begin{array}{l}14 \\
(19.7)\end{array}$ & $\begin{array}{l}6 \\
(8.5)\end{array}$ & $\begin{array}{l}17 \\
(23.9)\end{array}$ & $\begin{array}{l}34 \\
(47.9)\end{array}$ & 2.13 & 0.877 \\
\hline
\end{tabular}

Table 4 shows that (47.9 and 23.9) agree that the working with OER is on trial an error while 47.9 and 23.9) which may appear the same set of undergraduates uses OER to learn at their comfortable pace. As first year undergraduates, it is good to note that (42.3 and 35.2) were not intimidated but developed more confidence (57.7 and 15.5) in the use of OER. This supported Rogers (2003) and Mbati and Minnar (2015) that believed that trialability is positively related to the likelihood of adoption.

\section{Research Question 4: Is the Result of Using OER Visible to You? (Learners?)}

Table 5

Observation Recorded on the Use of OER

\begin{tabular}{|l|l|l|l|l|l|l|}
\hline Items & \multicolumn{3}{|l|}{ Frequency (\%) } & \multicolumn{2}{l|}{ Mean response rating } \\
\hline \hline & SD & D & A & SA & Mean & SD \\
\hline $\begin{array}{l}\text { I am aware of OER before I } \\
\text { got admission }\end{array}$ & $\begin{array}{l}11 \\
(15.5)\end{array}$ & $\begin{array}{l}24 \\
(33.8)\end{array}$ & $\begin{array}{l}18 \\
(25.4)\end{array}$ & $\begin{array}{l}18 \\
(25.4)\end{array}$ & 2.61 & 1.035 \\
\hline
\end{tabular}




\begin{tabular}{|l|l|l|l|l|l|l|}
\hline OER makes teaching real & $\begin{array}{l}18 \\
(25.4)\end{array}$ & $\begin{array}{l}15 \\
(21.1)\end{array}$ & $\begin{array}{l}20 \\
(28.2)\end{array}$ & $\begin{array}{l}18 \\
(25.4)\end{array}$ & 2.46 & 1.13 \\
\hline
\end{tabular}

\begin{tabular}{|l|l|l|l|l|l|l|}
\hline $\begin{array}{l}\text { I have seen other schools } \\
\text { using OER }\end{array}$ & $\begin{array}{l}25 \\
(35.2)\end{array}$ & $\begin{array}{l}33 \\
(46.5)\end{array}$ & $\begin{array}{l}8 \\
(11.3)\end{array}$ & $\begin{array}{l}5 \\
(7.0)\end{array}$ & 1.90 & 0.864 \\
\hline
\end{tabular}

Table 5 indicates that majority of undergraduates (46.5 and 35.2) have not seen the use of OER before or heard from other schools. This shows the background of the learners and difficulty they experience during the period of their transition from secondary school to tertiary institutions. However, (25.4 and 25.5) percentage are aware of OER before they got admission but do not use it. It is interesting to note that (25.4 and 28.2) agreed that OER made teaching real. This is in line with Rogers (2003) assertion that if observability is positively received then the rate of adoption is greater.

\section{Research Question 5: Is OER Difficult to Use and Understand?}

Table 6

Complexity of the OER

\begin{tabular}{|l|l|l|l|l|l|l|}
\hline Items & \multicolumn{1}{l|}{ Frequency (\%) } & Mean response rating \\
\hline & SD & D & A & SA & Mean & SD \\
\hline
\end{tabular}

\begin{tabular}{|l|l|l|l|l|l|l|}
\hline $\begin{array}{l}\text { When using OER, I } \\
\text { find it easy to navigate } \\
\text { from one screen to } \\
\text { another }\end{array}$ & $\begin{array}{l}10 \\
(14.1)\end{array}$ & $\begin{array}{l}4 \\
(5.6)\end{array}$ & $\begin{array}{l}23 \\
(32.4)\end{array}$ & $\begin{array}{l}34 \\
(47.9)\end{array}$ & 2.30 & 0.782 \\
\hline
\end{tabular}

\begin{tabular}{|l|l|l|l|l|l|l|}
\hline $\begin{array}{l}\text { Am confident in my } \\
\text { ability to use OER }\end{array}$ & 13 & 7 & 23 & 28 & 2.06 & 0.954 \\
\hline
\end{tabular}

Table 6 reveled that (40.8 and 28.2) agreed that OER is user friendly while (47.9 and 32.4) also found OER easy to navigate. This might have built in them confidence and believe in the use of OER. This also indicates that it is a good condition for students to work independently. 


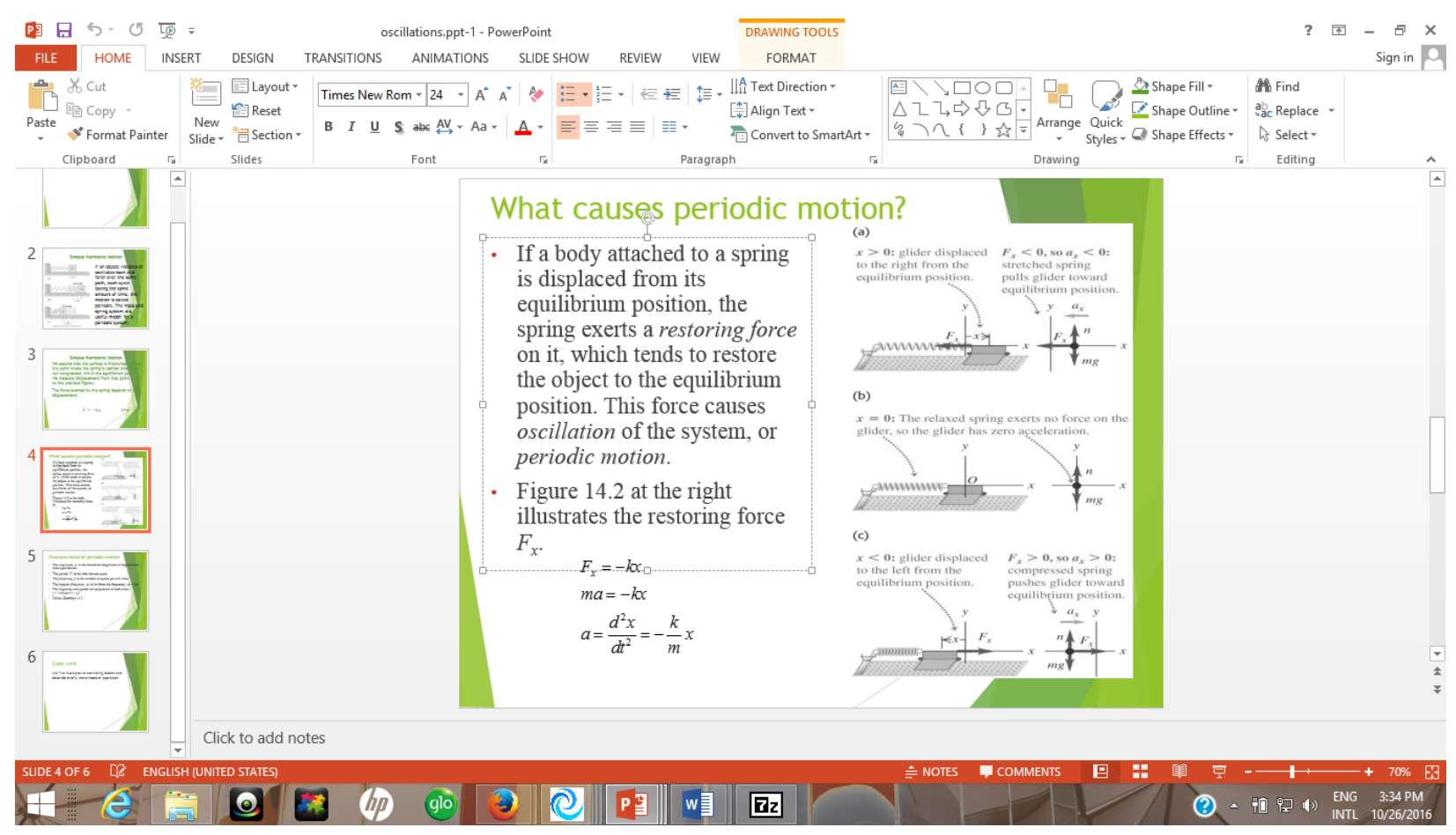

Figure 1. Sample of audiovisual OER (screen shot).

Based on the results of the preliminary study which showed a positive acceptability and willingness to make use of OER by the undergraduates, an intervention was designed and carried out to ascertain if OER could help at improving undergraduates' achievement in difficult concepts in Physics and as identified. Thirty-five undergraduates who did not participate in the preliminary study because of late registration, were used as control while 71 undergraduates who participated in the preliminary study were used for the experiment. The interaction with both groups went on simultaneously. The control group interacted on the LMS without the facilitator introducing any other learning support services whereas OER was introduced at every stages of interaction on the LMS ranging from video clips, audio, additional delivery notes, among others, to facilitate learning. Before the commencement, the researcher deployed achievement test titled OER Physics Achievement Test (OPAT) on the LMS (multiple choice with only one distracter), learners were given 24 hours to answer with only one attempt, thereafter, the results were downloaded for marking which served as the pre-test score for the participants.

The researcher introduced the treatment which lasted for four weeks with the help of a facilitator. Then, the posttest was administered and results analysed. Hypotheses were tested at $\mathrm{p}<0.05$ and the result were as follows: 


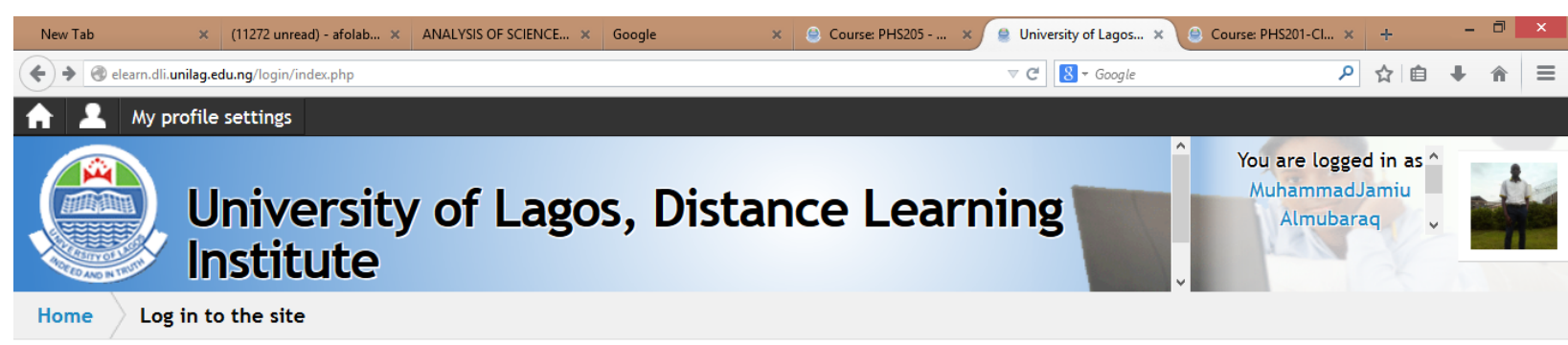

You are already logged in as MuhammadJamiu Almubaraq ABUBAKAR, you need to log out before logging in as different user.

Log out Cancel

F.

Figure 2. Student login page (screen shot).

Hypothesis I: There is no Significant Difference Between Achievement of First Year Undergraduates Exposed to the Use of OER and Those not Exposed to OER

Table 7

Descriptive Statistics and t-test for Equality of Means

\begin{tabular}{|c|c|c|c|c|c|c|c|c|c|c|c|}
\hline \multirow[t]{2}{*}{ Score } & \multirow[t]{2}{*}{ Treatment } & \multicolumn{4}{|c|}{$\begin{array}{c}\text { Group descriptive } \\
\text { statistics }\end{array}$} & \multicolumn{2}{|c|}{$\begin{array}{c}\text { Levene's } \\
\text { test for } \\
\text { equality of } \\
\text { variances }\end{array}$} & \multicolumn{4}{|c|}{ Equality of means for $t$-test } \\
\hline & & $\mathbf{N}$ & IMean & SD & 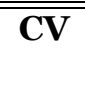 & $\overline{\bar{F}}$ & Sig. & $\begin{array}{c}\text { Mean } \\
\text { Difference }\end{array}$ & $\overline{\bar{T}}$ & dff & Sig. \\
\hline Pre-test & $\begin{array}{l}\text { Exposed to } \\
\text { OER }\end{array}$ & 71 & 9.68 & 5.419 & 0.56 & 2.393 & 0.125 & 1.876 & 2.035 & 104 & 0.045 \\
\hline $\begin{array}{l}\text { achievement } \\
\text { Score }\end{array}$ & \begin{tabular}{|l|} 
Not \\
exposed to \\
OER \\
\end{tabular} & 35 & 7.80 & 3.909 & 0.50 & & & & & & \\
\hline Post-test & $\begin{array}{l}\text { Exposed to } \\
\text { OER }\end{array}$ & 71 & 63.11 & 1212.145 & 0.19 & 1.158 & 0.284 & 40.198 & 17.630 & 104 & 0.000 \\
\hline $\begin{array}{l}\text { achievement } \\
\text { Score }\end{array}$ & $\begin{array}{l}\text { Not } \\
\text { exposed to } \\
\text { OER }\end{array}$ & 35 & 22.91 & 10.453 & 0.46 & & & & & & \\
\hline
\end{tabular}

${ }^{*}$ Note. $\mathrm{SD}=$ Standard Deviation, $\mathrm{CV}=$ Coefficient of Variation 
The descriptive statistics indicates that the mean pre-test achievement score for the respective groups is obtained as 9.68 (Exposed to OER) and 7.80 (Not exposed to OER) with CV $=0.56$ and $0.51>0.50$ threshold value, respectively, indicating that the scores are not homogeneous. The test for significance difference is carried out using independent samples t-test. The result indicates that, when unequal variances are assumed based on Levene's test, there is a significant mean difference (1.876) between undergraduates exposed to OER and undergraduates not exposed to OER on pre-test achievement scores at $\mathrm{t}=2.035(\mathrm{p}<0.05)$. The null hypothesis is rejected; there is significant difference between undergraduates exposed to OER and those not exposed. Hence, better performance is achieved when the undergraduates are exposed to OER. Further, the mean post-test achievement score for the respective groups is obtained as 63.11 (Exposed to OER) and 22.91 (Not exposed to OER) with CV $=0.19$ and $0.46<$ 0.50 threshold value, respectively, indicating that the scores are homogeneous. The independent samples t-test result indicates that, when unequal variances are assumed based on Levene's test, there is a significant mean difference (40.198) between undergraduates exposed to OER and students not exposed to OER on post-test achievement scores at $\mathrm{t}=17.630(\mathrm{p}<0.05)$. The null hypothesis is rejected, and concluding that there is significant difference between undergraduates exposed to the use of OER and those not exposed. Hence, better performance is achieved on exposure to OER.

\section{Hypothesis II: There is no Significant Difference Between Pre-Test and Post-Test Performances of Undergraduates Exposed to OER and Those not Exposed to OER}

Table 9

Descriptive Statistics and t-test for Equality of Means

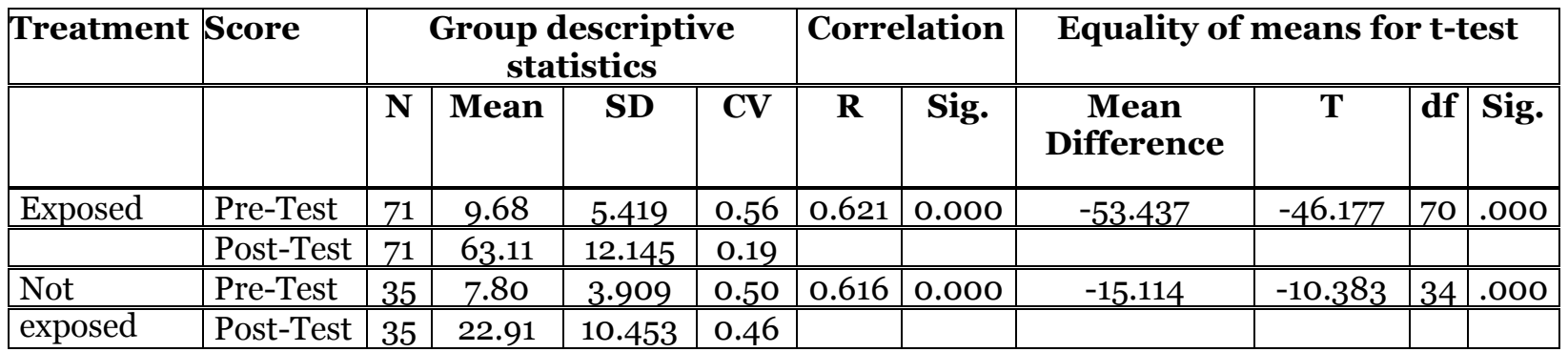

${ }^{*}$ Note. $\mathrm{SD}=$ Standard Deviation, $\mathrm{CV}=$ Coefficient of Variation

The descriptive statistics indicates that the mean pre-test and post-test achievement score for the undergraduates exposed to OER is obtained as 9.68 (Pre-test) and 63.11 (Post-test) with CV $=0.56>0.50$ and $0.19<0.50$ threshold value, respectively, indicating that the scores are homogeneous in post-test while not homogeneous in pre-test. The test for significance difference is carried out using pairwise samples ttest. The result indicates that, there is significant mean difference (-53.437) between pre-test and post-test achievement score of undergraduates exposed to OER at $\mathrm{t}=-46.177(\mathrm{p}<0.05)$. The null hypothesis is rejected; there is significant difference between pre-test and post-test performances of undergraduates exposed to OER. Hence, undergraduates' performance is better in the post-test achievement test. Further, the mean pre-test and post-test achievement score for the undergraduates not exposed to OER is obtained as 7.80 (Pre-test) and 22.91 (Post-test) with $\mathrm{CV}=0.50,0.46 \leq 0.50$ threshold value, respectively, indicating that the scores are homogeneous for both tests. The pairwise samples t-test result indicates that there is significant mean difference (-15.114) between pre-test and post-test achievement score of 
undergraduates not exposed to OER at $\mathrm{t}=-10.383(\mathrm{p}<0.05)$. The null hypothesis is rejected, and concluding that there is significant difference between pre-test and post-test performances of undergraduates not exposed to the use of OER. Hence, post-test performance is better. The correlation analysis shows that there is a significant relationship between pre-test and post-test for both exposed and not exposed to the use of OER at $\mathrm{r}=0.621$ and $0.616(\mathrm{p}<0.05)$, respectively.

\section{Findings}

From the data gathered from the study it was clearly shown that understanding of online learners' skills, acceptability, perception, and competencies is necessary to provide intervention strategy which could facilitate their understanding and learning of difficult concepts. This is what the preliminary study conducted has managed to expose.

The study also noted that students that have positive perception of OER performed very well in the achievement test administered. This might have been one of the reasons while significant difference occurred among the undergraduates exposed to the use of OER.

OER can successfully improve learners understanding of difficult concepts in Physics. It was found out that a significant relationship exist between the pre-test and post-test for both exposed and not exposed to the use of OER respectively.

\section{Recommendations}

The online education has come to stay as an acceptable mode of education and rapidly growing in developing countries of the world. There is the need to develop skills and technology applications among online learners. The findings of this study could inform that there is need to guide, support, and enhance online learning to reduce the dropout rate. In the same vein, facilitators should make use and engage their learners using OER to facilitate learning.

Efforts should be geared towards promoting online application and emerging technologies for online teaching. Facilitators should be trained in the use of emerging technology which can facilitate understanding of learners.

\section{Conclusion}

This study investigated first year University Undergraduates experience when expose to the use of OER in teaching difficult concepts in physics. According to DLI undergraduates, introduction of OER makes learning real and exposure to the new technology changed their perception and attitude to understanding difficult concept in Physics. High achievers are very satisfied with the use of OER, find OER to be convenient and flexible, are very engaged with their studies, and appeared to learn key concepts better. This conclusion however, is tempered by many limitations. Some OER videos which learners prefer most are of poor quality and sound. Another challenge is high data consumption rate which make the use of 
OER expensive. To this end, distance educators should provide wide range of learning support services to distance learners which will enhance their academic achievement not only in Physics but all courses. It is evident that OER is useful and its use must be encouraged in teaching and learning among distance learning institutions especially in developing countries.

\section{Acknowledgement}

A special thanks goes to all 2014/2015 academic session first year University undergraduates of Distance Learning Institute, University of Lagos for accepting to participate and supply information during the study.

\section{References}

Baloyi, G.P. (2014). Learner support in the open distance learning and e-learning context using the community of inquiry model. Mediterranean Journal of Social Sciences, 5(20), 1251-1258.

D'Antoni, S (2009). Open educational resources: Reviewing initiatives an issues. Open Learning: The Journal of Open, Distance, and E-learning. 24(1), 3-10.

Downes, S. (2011). From open content to open thinking. In the World Conference on Educational Multimedia, Hpermedia and Telecommunications (Ed-media, 2010). Toronto, Canada.

Govender, D.W., Dhurup, M., \& Mudaly, Y. (2014). Perception of learners of a learning management system to support teaching and learning using the diffusion of innovation theory. Mediterranean Journal of Social Sciences, 5(8), 377-385.

Harsasi, M. (2015). The use of open educational resources in online learning. A study of students' perception. Turkish Online Journal of Distance Education, 16(3), 74-87.

Hew, K.F., \& Cheung, W.S (2013). Use and production of open educational resources (OER). A pilot study of undergraduate students' perceptions. Conference proceeding of International Conference on Educational Technology, 125-128.

Hilton, J., III, \& Laman, C. (2012). One college's use of open psychology textbook-open learning. The Journal of Open, Distance and E-learning, 27(3), 265-272. Doi: https//doi.org/10.7080/02680513.2012.716657

Hylen, J. (2007). Giving knowledge for free: the emergence of open educational resources. Retrieved from http://www.oecd.org//dataoecd/35/7/386654317.pdf 
Kember, D., McNaught, C., Chong, F.C., Lam, P., \& Cheng, K.F. (2010). Understanding the ways in which designs features of educational websites impacts upon students learning outcomes in blended learning environments. Computers in Education, 55, 1183-1192.

Mbati, L., \& Minnar, A. (2015). Guidelines towards the facilitation of interactive online learning programmes in higher education. International Review of Research in Open and Distributed Learning, 16(12), 272-286.

McCarthy, J. (2010). Blended learning environments: Using social networking sites to enhance the first year experience. Australasian Journal of Educational Technology, 26(6), 729-740.

Organisation for Economic Co-operation and Development. (2007). Giving knowledge free: the emergence of open education resources. Organization for Economic Co-operation and Development, Paris, France.

Ownioduokit, F.A. (2000). Knowledge of mathematics as a predator of students' performance in physics. Nigerian Journal of Science Education, 6(1), 9-15.

Prensky, M. (2001). Digital native, digital immigrants. On the Horizon, 9(5), 1-6.

Resis. M., \& Steffens, D. (2010). Hybrid toolboxes: Conceptual and empirical analysis of blending patterns in application of hybrid media. Technological and Economic Development of Economy, 16(2), 305-326.

Rumble, G. (2000). Student support in distance education in 21st century learning from service management. Distance Education, 121(2) 216-235.

Rogers, E.M. (2003). Diffusion of innovations (5th ed.) New York: Free Press.

Secreto, P.V. (2013). Gender equality in online learning: the case of Up Open University. Proceia-Social and Behavioural Sciences, 103, 434-441.

Sclater, N. (2010). The organizational impact of open educational resources. In Changing Cultures in Higher Education. Springer Berlin Heidelberg.

\section{Athabasca} University

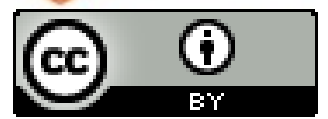

